\title{
New records of two species of Sabellaria (Polychaeta: Sabellariidae) from the Argentinean Biogeographic Province
}

\author{
Nuevos registros de dos especies de Sabellaria (Polychaeta: Sabellariidae) en \\ la Provincia Biogeográfica Argentina \\ Claudia S. Bremec and Diego A. Giberto \\ Consejo Nacional de Investigaciones Científicas y Técnicas (CONICET), Argentina \\ Instituto Nacional de Investigación y Desarrollo Pesquero (INIDEP), Laboratorio de Bentos \\ Paseo V. Ocampo No 1, B7602HSA Mar del Plata, Argentina \\ cbremec@inidep.edu.ar
}

\begin{abstract}
Sabellaria bellis Hansen, 1882 and S. wilsoni Lana \& Gruet, 1989 were recorded in different habitats from coastal localities of Uruguay and Argentina, between $34^{\circ} \mathrm{S}$ and $37^{\circ} \mathrm{S}$, Argentinean Biogeographic Province. Local distribution patterns in relation with the hydrography are discussed. Our findings show that both species are tolerant to salinity changes.
\end{abstract}

Key words: polychaetes, benthos, distribution, South Atlantic

\section{Introduction}

The Sabellariidae Johnston, 1865, placed within the Sabellida (Rouse \& Fauchald 1997), comprise noncolonial or colonial reef-builder worms, which occur from shallow to deep waters (Uebelacker 1984); colonies are formed by mass settlement (Eckelbarger 1977).

Four species of Sabellaria Savigny, 1818 have been found in the Southwestern Atlantic Ocean: S. bella Grube, 1870, S. bellis Hansen, 1882, S. nanella Chamberlin, 1919 and S. wilsoni Lana \& Gruet, 1989 (Bremec \& Lana 1994, Lana \& Bremec 1994). All of them were recorded in southeastern Brazil (Espiritu Santo, Rio de Janeiro, Santa Catarina and Paraná States, 20-32 $2^{\circ}$ ) and the last two species in Argentina (Monte Hermoso, $\left.39^{\circ} \mathrm{S}\right)$. This paper reports the presence of $S$. bellis on different substrates in southern littoral latitudes of Uruguay (34-35 ${ }^{\circ}$ S), and S. wilsoni associated to reefs of Ficopomatus enigmaticus Fauvel, 1923, in a marine coastal lagoon of Argentina $\left(37^{\circ} \mathrm{S}\right)$ and discusses local patterns of distribution.

\section{Taxonomy}

\section{Sabellaria bellis Hansen, 1882}

Sabellaria bellis Hansen, 1882: 19, pl. 6, figs. 5-17; Augener, 1934: 149, fig. 30 a-e; Hartman, 1944: 339,
Resumen.- Sabellaria bellis Hansen, 1882 y S. wilsoni Lana \& Gruet, 1989 fueron registradas en diversos habitats costeros de Uruguay y Argentina, entre $34^{\circ} \mathrm{S}$ y $37^{\circ} \mathrm{S}$, Provincia Biogeográfica Argentina. Se discuten los patrones de distribución local en relación con la hidrografía. Nuestros resultados indican que ambas especies son tolerantes a los cambios de salinidad.

Palabras clave: poliquetos, bentos, distribución, Atlántico Sur

pl. 30, figs. 27-29; Rullier \& Amoureux, 1979: 188; Gruet \& Lana, 1988: 34, figs. 3-4; Kirtley, 1994 : 55, figs.4.5.1-4.5.2 ; Lana \& Bremec, 1994: 213, fig. 1-2.

\section{Material examined}

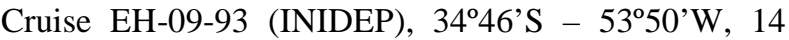
specimens, Piccard dredge, $23 \mathrm{~m}$, sandy coarse bottom, 31.53 psu, August 1993, C.B. coll., Benthos Lab. INIDEP collection. Cruise EH-12-97 (INIDEP),

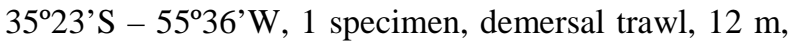
sandy bottom, 29.9 psu, November 1997, E. Spivak coll., Invertebrates Lab. National Univ. Mar del Plata collection.

\section{Remarks}

The specimens fit well with the diagnosis and descriptions of Lana \& Bremec (1994) and Gruet \& Lana (1988). Diagnostic characters include external paleae with spiny median spike and two lateral teeth, middle paleae short, spoon-shaped and crenulated, and inner paleae long, concave and distally spiny. Length of individuals between $24,3 \mathrm{~mm}$ and $48,2 \mathrm{~mm}$.

\section{Biological comments}

The 14 specimens collected at $23 \mathrm{~m}$ depth were part of an assemblage of 34 species, with abundant specimens of the crabs Pelia rotunda Milne Edwards, 1875, Libinia spinosa Milne Edwards, 1934 and Pachycheles 
chubutensis Boschi, 1963; the echinoderms Ophioplocus januarii (Lütken, 1856) and Patiria stellifer (Möbius, 1859), the polychaetes Nephtys sp. and Serpulidae, as well as the bivalve Ostrea puelchana d'Orbigny, 1842 (Giberto 2001). Tubes of Sabellaria bellis were hard, made of sand grains, and found as epibionts of Ostreidae in sandy bottoms.

The specimen found in more coastal waters

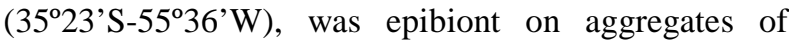
Phyllochaetopterus socialis Claparède, 1868 attached to a hard substrate (Obenat et al. 2001). In this case, the tube was friable, made of small sand grains. A diverse fauna of eleven phyla was associated to the mats, and the most abundant were the polychaetes Hydroides plateni (Kinberg, 1867), different Syllidae, and the bryozoan Aetea anguina (Linné, 1758).

\section{Distribution}

Sabellaria bellis is known from southeastern Brazil (Río de Janeiro and Santa Catarina States). The new records extend the southern limit to marine coastal waters adjacent to the mouth of the Río de la Plata estuary (Fig. 1).

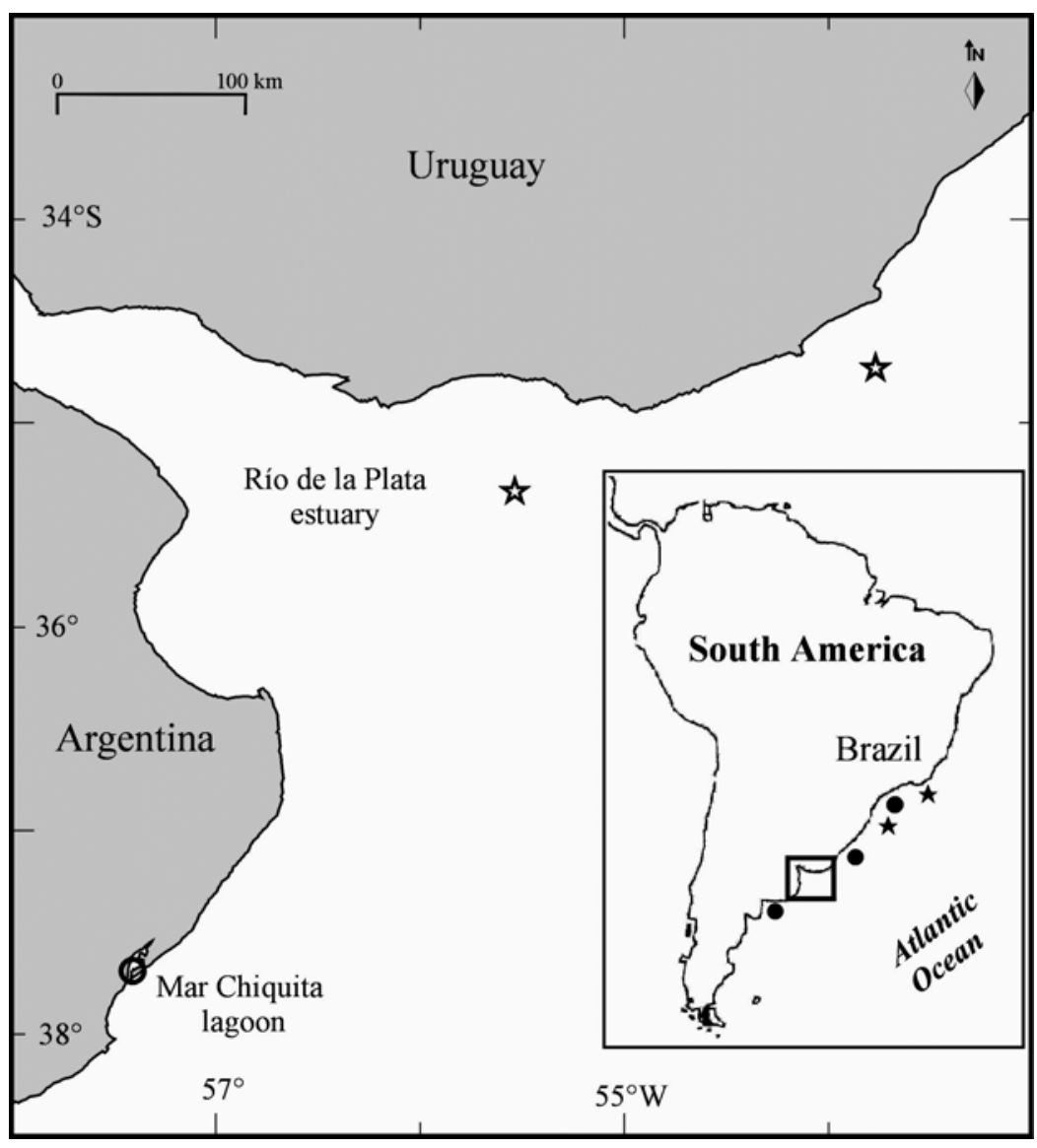

Figure 1

Geographic distribution of Sabellaria bellis (star) and Sabellaria wilsoni (circle), indicating the location of new (empty) and previous (full) records in the southern Atlantic

Distribución geográfica de Sabellaria bellis (estrella) y Sabellaria wilsoni (círculo), indicando la localidad de registros nuevos (vacío) y previos (lleno) en el Atlántico sur 


\section{Sabellaria wilsoni Lana \& Gruet, 1989}

Sabellaria wilsoni Lana \& Gruet, 1989: 239, figs. 1-21; Bremec \& Lana, 1994: 49, fig.1d-f; Kirtley, 1994: 80, fig. 4.33; Lana \& Bremec, 1994: 214, figs. 1m-2.

\section{Material examined}

Mar Chiquita coastal lagoon, San Gabriel, 3704'S$57^{\circ} 22^{\prime} \mathrm{W}, 1$ specimen, $1 \mathrm{~m}$, sandy bottom, March 2001, S. Obenat coll., Invertebrates Lab. National Univ. Mar del Plata collection.

\section{Remarks}

The specimen fits well with the description and diagnosis of Lana \& Gruet (1989) and Lana \& Bremec (1994) respectively. Diagnostic characters include external paleae asymetrical and distally spinous with a central spike, middle paleae basally concave with two lateral expansions, and inner paleae geniculated, basally excavated and distally pointed. Total length of the specimen $8,1 \mathrm{~mm}$.

\section{Biological comments}

Specimen collected as biota associated to reefs of Ficopomatus enigmaticus Fauvel, 1923, the most austral location registered for the species (Obenat, 2002). Conspicuous associated species were the amphipod Melita sp., the crab Cyrtograpsus angulatus Dana, 1851; the polychaetes Neanthes succinea (Frey \& Leuckart, 1847) and Laeonereis acuta Treadwell, 1923, as well as the gastropods Heleobia spp. (Obenat, 2002). Tube of Sabellaria wilsoni friable, made of small sand grains.

\section{Distribution}

The species is known from Paraná State (2530'S, Brazil), Monte Hermoso (395, Argentina) and probably the French Guyana, between 6 and 16,5 m depth (Lana \& Gruet, 1989). This new locality, Mar Chiquita coastal lagoon (Fig. 1), represents a highly variable environment, strongly influenced by tides, with a salinity annual range 0,5 to 34 (Reta et al. 2001).

\section{Discussion}

Gaylord \& Gaines (2000) explored the potential of ocean flows to generate distributional patterns, through their influence on recruitment processes of marine species with dispersing larvae. They suggested that biogeographic boundaries worldwide, often associated with flow fields, can function as one- or two-way barriers to range expansion of larvae and may be differentially permeable depending on their life-history characteristics. The importance of transport mechanisms in nearshore systems, obviously including estuaries and coastal lagoon mouths, is stressed out by Pineda (2000), while hydrodynamic processes influencing the larval pool, physical transport, microhydrodynamics, substrate availability and behavior are considered the main phenomena influencing settlement (Pineda 1994).

The studied material was collected in the warm temperate waters of the Argentine Biogeographic Province (Boschi 2000a). It includes coastal waters from $43-44^{\circ} \mathrm{S}$ (Patagonia) to $23^{\circ} \mathrm{S}$ (southern Brazil). This part of the Southwestern Atlantic Ocean is interesting for many reasons, as the Argentine Province is influenced by subtropical and subantarctic waters, Brazilian and Magellanic, respectively, and also divided by the Río de la Plata $\left(35^{\circ} \mathrm{S}\right)$ (Boltovskoy et al. 1999; Boschi 2000a), the major hydrographical feature within this province (Boschi 2000b).

This barrier was found to be intermittent for southbrazilian plankton and fish species, according to climatic variation and discharge patterns of the river (Mianzan et al. 2001a). Many taxa of decapods (Melo 1990, Boschi 2000a, Scelzo 2001, Schejter et al. 2002) and cnidarians (Zamponi 2000) also show affinity between southern Brazil and the littoral of northern Argentina (38ㅇ). Oceanographic dynamic also favors physical transport from southern (Argentinean) to northern (Brazilian) shelf areas, and the translocation of species to estuarine waters is also possible (Guerrero \& Piola 1997, Piola \& Rivas 1997). Continental shelf water, originally subantarctic, intrudes upriver below the diluted upper layer and remains unaltered under most wind conditions (Mianzan et al. 2001b). However, it is considered that the dispersal of some invertebrates from south to north, and within estuarine waters, could be constrained due to thermal and salinity tolerance (Melo 1990, Giberto \& Bremec 2003).

Sabellariids are characterized by long life span, very high fecundity and high dispersal capability; planktotrophic larvae remain in the plankton for long periods and are able to cross oceanic distances (Giangrande 1997). Larval settlement seems to be induced by the presence of con-specific reefs in gregarious species, while those of solitary species do not show this preference; larvae of a reef-forming sabellariid responded first to proper flow conditions and then to chemical cues that induced metamorphosis under experimental small spatial scales (Pawlik 1988, Pawlik et al. 1991). 
Regarding sabellariids in South America, a disjunctive distribution was suggested as an actual zoogeographical pattern in a continental scale, with endemic or restricted geographical patterns (Lana \& Bremec 1994). S. bellis was recorded on different settlement substrates, Ostreidae in Uruguayan marine waters and Phyllochaetopterus socialis mats in estuarine waters off Rio de la Plata; these records extend its southern distributional range from SE Brazil, where the known distribution was restricted (Lana \& Bremec 1994, Obenat et al. 2001). S. wilsoni was collected in a shallow habitat with variable seasonal salinity, totalizing four individuals in patches of 150 $\mathrm{cm}^{2}$ in Ficopomatus enigmaticus reefs (Obenat 2002, pers. comm). These findings show that both species are tolerant to salinity changes; local nearshore patterns of circulation, and larval transport, permit Sabellaria species to colonize new coastal areas.

In conclusion, many authors consider the freshwater discharge of the Rio de la Plata and its adjacent area as a significant zoogeographic barrier for the distribution of several marine groups, particularly for the cold temperate species, while others emphasize it is a transitional zone with a high degree of mixing of faunal regimes (Bisbal 1995). Future research is needed to assess the local distribution of coastal polychaete fauna within the Argentine Province, together with the tolerance of every species to salinity and temperature variations and availability of primary settlement substrate.

\section{Acknowledgements}

We are indebted to Dr. S. Obenat for study material and to Drs. E. Marcelo Acha and Hermes W. Mianzan for helpful comments. This study was partially supported by Fundación Antorchas $\mathrm{N}^{\mathrm{o}} 13817-5$ and Agencia Nacional de Promoción Científica y Tecnológica $\mathrm{N}^{\mathrm{o}}$ 8424 grants to HWM and PEI 6026 to CB. This is INIDEP Contribution $\mathrm{N}^{\circ} 1343$.

\section{Literature cited}

Augener H. 1934. Polychaeten aus den Zoologischen Museen von Leiden und Amsterdam. 4. Zoologische Mededelengen, Leiden, 17: 67-160.

Bisbal GA. 1995. The Southeast South American shelf large marine ecosystem. Evolution and components. Marine Policy 19: 21-38.

Boltovskoy D, MJ Gibbons, L Hutchings \& D Binet. 1999. General biological features of the South Atlantic. In: D Boltovskoy (ed), South Atlantic Zooplankton, pp. 1-42. Backhuys Publishers, Leiden.
Boschi EE. 2000a. Species of decapod crustaceans and their distribution in the American marine zoogeographic provinces. Revista de Investigación y Desarrollo Pesquero, 13: 7-136.

Boschi EE. 2000b. Biodiversity of marine decapod brachyurans of the Americas. Journal of Crustacean Biology, 20: 337-342.

Bremec CS \& PC Lana. 1994. New records of Sabellariidae (Annelida, Polychaeta) from Argentina. Neritica 8: 47-53.

Eckelbarger KJ. 1977. Larval development of Sabellaria floridens from Florida and Phragmatopoma californica from Southern California (Polychaeta: Sabellariidae), with a key to the sabellariid larvae of Florida and a review of development in the family. Bulletin of Marine Science, 27: 241-255.

Gaylord B \& SD Gaines. 2000. Temperature or transport? Limits in marine species mediated solely by flow. American Naturalist, 155: 769-789.

Giangrande A. 1997. Polychaete reproductive patterns, life cycles and life histories: An overview. Oceanography and Marine Biology Annual Review, 35: 323.386.

Giberto DA. 2001. Fondos de alimentación de la corvina rubia en el estuario del Río de la Plata. Tesis de Licenciatura, Facultad de Ciencias Exactas y Naturales, Universidad Nacional de Mar del Plata. 83 pp.

Giberto DA \& CS Bremec. 2003. Ebalia rotundata A. Milne-Edwards, 1880 (Brachyuran, Leucosiidae) in marine waters off Uruguay and Argentina. Crustaceana 76: 307-312.

Gruet Y \& PC Lana. 1988. Remarks on the opercular paleae of Sabellaria bella Grube, 1870 and Sabellaria bellis Hansen, 1882 (Sabellariidae; Polychaeta) from the southeast coast of Brazil. Neritica 3: 31-36.

Guerrero RA \& AR Piola. 1997. Water masses in the continental shelf. In: EE Boschi (ed), The Argentine Sea and its fisheries resources. Historical review of the exploratory cruises and the environmental characteristics of the western South Atlantic Ocean, pp. 107-118. Instituto Nacional de Investigación y Desarrollo Pesquero, Mar del Plata, Argentina.

Hansen A. 1882. Recherches sur le Annélides recueillies par M. Le professeur Edouard Van Beneden pendant son voyage au Brésil et à la Plata. Mèmoires Couronnés Académie Royale Sciences Belgique, Bruxelles, 44: 1-29.

Hartman O. 1944. Polychaetous Annelids, Part VI. Paraonidae, Magelonidae, Ctenodrilidae and Sabellariidae. Allan Hancock Pacific Expedition 10: 311-389.

Kirtley DW. 1994. A review and taxonomic revision of the family Sabellariidae Johnston, 1865 (Annelida; Polychaeta). Sabecon Press, Florida. 223 pp. 
Lana PC \& CS Bremec. 1994. Sabellariidae (Annelida, Polychaeta) from south America. In: J-C Dauvin, L Laubier \& DJ Reish (eds), Actes de la 4ème Conférence internationale des Polychètes, Mémoires Muséum National d'Histoire Naturelle, Paris, 162: 211-222.

Lana PC \& Y Gruet. 1989. Sabellaria wilsoni sp.n. (Polychaeta, Sabellariidae) from the southeast coast of Brazil. Zoologica Scripta, 18: 239-244.

Melo GAS De. 1990. A presencia no litoral sudeste brasileiro, de espécies de Brachyura (Crustacea: Decapoda) originárias das regiones biogeográficas Magelanica e Argentina do Atlantico Sul. Atlantica, 12: 71-83.

Mianzan HW, EM Acha, RA Guerrero, FC Ramírez, D Sorarrain, C Simionato \& J Borus. 2001a. South Brazilian marine fauna in the Río de la Plata estuary: discussing the barrier hypothesis. Resúmenes Ampliados IX $^{0}$ Congreso Latinoamericano de Ciencias del Mar (COLACMAR), San Andrés, Colombia, (CD-ROM), 4 pp.

Mianzan H, C Lasta C, M Acha, R Guerrero, G Macchi \& CS Bremec. 2001b. Río de la Plata estuary: ecological profile of a large scale salt wedge. In: U Seeliger \& B Kjerve (eds), Coastal Marine Ecosystems of latin America, pp. 185-204. Springer Verlag, Berlin.

Obenat S. 2002. Estudios ecológicos de Ficopomatus enigmaticus (Polychaeta: Serpulidae) en la laguna Mar Chiquita, Buenos Aires, Argentina. Tesis Doctoral, Facultad de Ciencias Exactas y Naturales, Universidad Nacional de Mar del Plata. 159 pp.

Obenat S, L Ferrero \& E Spivak. 2001. Macrofauna associated with Phyllochaetopterus socialis aggregations in the southwestern Atlantic. Vie et Milieu 51: 131-140.

Pawlik JR. 1988. Larval settlement and metamorphosis of Sabellariid Polychaetes with special reference to Phragmatopoma lapidosa, a reef building species, and Sabellaria floridens, a non gregarious species. Bulletin of Marine Science 43: 41-60.

Pawlik JR, CA Butman \& VR Starczak. 1991. Hydrodynamic facilitation of gregarious settlement of a reef-building tube worm. Science 251: 421-424.
Pineda J. 1994. Spatial and temporal patterns in barnacle settlement along a southern California rocky shore. Marine Ecology Progress Series 107: 125-138.

Pineda J. 2000. Linking larval settlement to larval transport: assumptions, potentials, and pitfalls. Oceanography Eastern Pacific 1: 84-105.

Piola AR \& AL Rivas. 1997. Currents in the continental shelf. In: EE Boschi (ed), The Argentine Sea and its fisheries resources. Historical review of the exploratory cruises and the environmental characteristics of the western South Atlantic Ocean, pp. 119-132. Instituto Nacional de Investigación y Desarrollo Pesquero, Mar del Plata, Argentina.

Reta R, P Martos, G Perillo, MC Piccolo \& A Ferrante. 2001. Características hidrográficas del estuario de la laguna Mar Chiquita. In: O Iribarne (ed), Reserva de Biosfera Mar Chiquita: características físicas, biológicas y ecológicas, pp. 31-52. Editorial Martín, Mar del Plata, Argentina.

Rouse GW \& K Fauchald. 1997. Cladistics and polychaetes. Zoologica Scripta 26: 139-204.

Rullier F \& L Amoureux. 1979. Campagne de la Calypso au large des côtes atlantiques de l'Amérique du sud (19611962). I. 33. Annélides Polychètes. Annales Institut Océanographique Monaco, 55 (Suppl.): 145-206.

Scelzo M. 2001. First record of the portunid crab Arenaeus cribarius (Lamarck 1818) (Crustacea: Brachyura: Portunidae) in marine waters of Argentina. Proceedings of the Biological Society of Washington, 114: 610-615.

Schejter L, E Spivak \& T Luppi. 2002. Presence of Pyromaia tuberculata (Lockington, 1877) adults and larvae in the Argentine continental shelf (Crustacea: Decapoda: Majoidea). Proceedings of the Biological Society of Washington, 115: 605-610.

Uebelacker JM. 1984. Sabellariidae. In: Uebelacker JM \& PG Johnson (eds), Taxonomic guide to the polychaetes of the northern Gulf of Mexico. Barry A. Vittor \& Associates, Louisiana. 7: 49.1-49.10.

Zamponi MO. 2000. El estuario del Río de la Plata: una barrera geográfica para los cnidarios bentónicos marinos?. Biociências 8: 127-136. 